\title{
Model nadzoru metrologicznego nad urządzeniami procesowymi do pomiaru THT
}

\section{A model of metrological supervision of process analyzers for THT measuring}

\author{
Anna Huszał \\ Instytut Nafty i Gazu - Państwowy Instytut Badawczy
}

\begin{abstract}
STRESZCZENIE: Rosnące zapotrzebowanie na analizatory procesowe stosowane w nadzorze procesu nawaniania paliw gazowych i związane z tym coraz wyższe wymagania ich użytkowników w zakresie jakości uzyskiwanego wyniku pociągają za sobą rosnące potrzeby weryfikacji poprawności działania tych urządzeń oraz potwierdzenia wiarygodności wyniku pomiaru. Obecnie brak jednak odpowiednich regulacji prawnych dotyczących sprawowania kontroli nad tego typu aparaturą, jak również precyzujących, z jaką niepewnością powinno być oznaczane stężenie środka nawaniającego w gazie. Istniejące w tym obszarze regulacje normatywne nie są jednoznaczne i mogą być różnie interpretowane, przez co często urządzenia procesowe do pomiaru stężenia tetrahydrotiofenu (THT) w gazie mogą pozostawać bez właściwego nadzoru metrologicznego. Niezbędny jest zatem właściwy dobór i weryfikacja odpowiednich metod kontroli poprawności wskazań ww. urządzeń procesowych oraz ich wdrożenie do programu okresowych sprawdzeń. Niezwykle pożądaną metodą nadzoru jest sprawdzanie lub wzorcowanie analizatorów w warunkach obiektowych (procesowych), bez potrzeby ich demontażu na czas sprawdzenia. Wiąże się to z koniecznością określenia możliwości prowadzenia nadzoru metrologicznego analizatorów procesowych do kontroli stężenia THT okresowo z wykorzystaniem urządzeń referencyjnych. W artykule przedstawiono porównanie dwóch metod stosowanych obecnie w nadzorze metrologicznym analizatorów procesowych do pomiaru stężenia THT w gazie ziemnym rozprowadzanym sieciami dystrybucyjnymi. Analizie poddano wyniki sprawdzeń poprawności działania tych urządzeń uzyskane metodą porównania z testem laboratoryjnym oraz metodą pomiarów porównawczych on-line. Przeprowadzone badania zweryfikowały główne źródła błędów, mające istotny wpływ na poprawność wyniku uzyskiwanego za pomocą wybranych testów sprawdzających. Otrzymane wyniki badań wykazały istnienie błędu systematycznego dla metody porównania z testem laboratoryjnym. Wykazały także możliwość stosowania metody pomiarów porównawczych on-line do przeprowadzania okresowych wzorcowań bądź sprawdzeń poprawności działania analizatorów THT w warunkach procesowych.
\end{abstract}

Słowa kluczowe: analizatory procesowe, nawanianie gazu, kontrola procesu nawaniania.

ABSTRACT: The increasing demand for process analyzers used in the supervision of the gaseous fuels odorizing process and the related higher and higher users' requirements in terms of the quality of the results obtained lead to the growing need to verify the correctness of operation thereof and to confirm the reliability of measurement results. At present, however, there are no appropriate legal regulations concerning the control over this type of apparatus, as well as specifying the uncertainty level that the gas odorant concentration should be determined with. The normative regulations existing in this area are not unequivocal and can be interpreted in different ways, which leads to the situation when process equipment for measuring tetrahydrothiophene (THT) concentration in the gas can often lack proper metrological supervision. It is therefore necessary to properly select and verify appropriate methods to control the correctness of the process equipment indications and their implementation into the periodic check program. An extremely desirable method of supervision is to check or calibrate the analyzers in process conditions, without their dismantling for the time of checking. In turn, this entails the necessity to determine the possibility of conducting periodic metrological supervision over the measurement results correctness of THT process analyzers with the use of reference devices. The article presents a comparison of two methods currently used in metrological supervision of process analyzers for measuring the concentration of THT in the natural gas distribution gird. The results of checks of the proper functioning of these devices obtained by means of comparison with the laboratory test and the on-line comparative measurement method were analyzed. The conducted research verified the main sources of errors that have a significant impact on the correctness of results obtained by means of selected test methods. The results obtained showed the existence of a systematic error for the comparison method with a laboratory test. They also demonstrated the possibility of using the on-line comparative measurement method to carry out periodic calibrations or checks of the correct operation of THT analyzers in process conditions.

Key words: process analyzers, gas odorization, odorization process control.

Autor do korespondencji: A. Huszał, e-mail: anna.huszal@inig.pl

Artykuł nadesłano do Redakcji: 18.03.2020 r. Zatwierdzono do druku: 07.12.2020 r. 


\section{Sposoby nadzoru metrologicznego analizatorów procesowych THT}

Z procesem nawonienia paliw gazowych nierozłącznie związany jest problem nadzoru nad nim, mający związek z kontrolą poziomu nawonienia gazu. Dominującym obecnie sposobem prowadzenia nadzoru nawaniania jest kontrola analityczna stężenia środka nawaniającego w gazie THT, której celem jest dostarczenie ilościowych informacji o przebiegu procesu nawaniania (Gromadzki, 2016; Laszuk, 2016). Niestety wymagania w stosunku do dokładności tego typu pomiarów nie są uregulowane prawnie (ze względu na to, że parametrem jakościowym gazu w tym zakresie jest intensywność zapachu gazu (Rozporządzenie Ministra Gospodarki z dnia 2 lipca 2010 r.)), a są zwykle ustalane $\mathrm{w}$ wewnętrznych procedurach przedsiębiorstw wykonujących pomiary lub stosownych umowach o świadczenie usługi nawaniania paliwa gazowego (jeżeli takie są zawierane).

Praktykowane obecnie oznaczenia analityczne, których celem jest dostarczenie ilościowych informacji o przebiegu procesu nawaniania, można podzielić zasadniczo na dwie kategorie, uwzględniając sam sposób prowadzenia pomiaru (PN-EN ISO 14532:2017):

1) pomiary w trybie off-line, do których zaliczyć należy pomiary laboratoryjne wykonywane $\mathrm{z}$ dala od gazociągu, a tym samym od miejsca poboru próbki (z użyciem próbki pobranej ze strumienia badanego gazu);

2) pomiary w trybie on-line, których szczególnym przypadkiem jest analiza procesowa; pomiary wykonywane są w trakcie prowadzenia procesu przez urządzenia pomiarowe zainstalowane na stałe lub okresowo w miejscu pobierania próbek; próbka jest pobierana automatycznie (przy zachowaniu odpowiedniego reżimu czasowego) przez analizator.

Zgodnie z zapisami normatywnymi (PN-C-04751:2011), dopuszczającymi pomiar stężenia środka nawaniającego $\mathrm{w}$ gazie w celu oceny jakości gazu w sieci przesyłowej, oraz z zapisami odpowiednich standardów technicznych Izby Gospodarczej Gazownictwa (ST-IGG-0705:2019) oznaczenia stężenia środka nawaniającego należy prowadzić metodami chromatograficznymi zgodnie z wymaganiami PN-EN ISO 19739:2010.

Norma PN-C-04751:2011 określa podstawowe wielkości stosowane w ocenie jakości gazu ziemnego doprowadzanego do odbiorców, ze wskazaniem metod pomiarowych i obliczeniowych służących do wyznaczania wartości tych wielkości. Zgodnie z zapisami normy jedną z wielkości zalecanych do oceny jakości gazu w sieci przesyłowej jest zawartość środka nawaniającego (jeżeli prowadzi się nawanianie w sieci przesyłowej). Oznaczenia zawartości środka nawaniającego w gazie należy wykonywać metodami opisanymi w normie PN-EN ISO 19739:2010. Norma PN-C-04751:2011 dopuszcza stosowanie także innych metod pomiaru stężenia środka nawaniającego, pod warunkiem że niepewność uzyskanych za ich pomocą wyników nie będzie większa niż ta, którą obarczone są wyniki otrzymane przy zastosowaniu metod opisanych normą PN-EN ISO 19739:2010, a stosowane analizatory będą regularnie wzorcowane.

Spośród wymienionych powyżej dokumentów jedynie norma 19739:2010 określa wymagane charakterystyki metod analizy związków siarki, w tym również THT (pkt 9 normy), określone na podstawie wyników badań biegłości. Wartości zgodności w badaniach biegłości, podane w normie PN-EN ISO 19739:2010, stanowią granice, pomiędzy którymi powinny mieścić się wyniki uzyskane przez dwa niezależne laboratoria analizujące ten sam materiał odniesienia, ale stosujące różne metody pomiarowe. Tabela 1 zawiera jedynie wyniki odnoszące się do THT. Na jej podstawie można stwierdzić, że przy porównywaniu wyników pomiarów stężenia THT uzyskanych przez dwa laboratoria (różne przyrządy pomiarowe, różne warunki wykonywania oznaczeń) dla gazu, w którym stężenie THT wynosi $25 \mathrm{mg} / \mathrm{m}^{3}$, za porównywalne można uznać wyniki, które mieszczą się w granicach $19 \mathrm{mg} / \mathrm{m}^{3}$ do $31 \mathrm{mg} / \mathrm{m}^{3}$, tj. $25 \mathrm{mg} / \mathrm{m}^{3} \pm 5 \mathrm{mg} / \mathrm{m}^{3}$ (20\% zgodności badań biegłości) $\pm 1 \mathrm{mg} / \mathrm{m}^{3}$ ( $4 \%$ osiągalnej powtarzalności).

Prowadzenie kontroli nawonienia gazu poprzez pomiary stężenia THT w gazie $\mathrm{w}$ trybie on-line $\mathrm{z}$ użyciem analizatorów procesowych jest dopuszczone przez standard IGG ST-IGG-0705:2019. Nie określa on jednak wymagań w stosunku do jakości wyników uzyskiwanych tymi analizatorami ani nie określa wymaganych parametrów metrologicznych tych urządzeń. Wskazuje natomiast wymagania w stosunku do wyniku uzyskanego klasyczną analizą chromatograficzną (pomiar laboratoryjny). Zgodnie ze standardem za wynik końcowy oznaczenia należy przyjąć średnią co najmniej dwóch pomiarów, których wyniki nie różnią się o więcej niż 4\%.

Tabela 1. Charakterystyka metody oznaczania THT wg PN-EN ISO 19739:2010

Table 1. Characteristics of the THT determination method according to PN-EN ISO 19739: 2010

\begin{tabular}{|c|c|c|c|c|}
\hline \multirow{2}{*}{ Związek } & $\begin{array}{c}\text { Stężenie masowe } \\
\text { (normalne warunki } \\
\text { odniesienia) }\end{array}$ & $\begin{array}{c}\text { Możliwa do uzyskania } \\
\text { powtarzalność (wartość } \\
\text { bezwzględna, normalne } \\
\text { warunki odniesienia) }\end{array}$ & $\begin{array}{c}\text { Możliwa do uzyskania } \\
\text { powtarzalność } \\
\text { (wartość względna) }\end{array}$ & $\begin{array}{c}\text { Uzyskana zgodność } \\
\text { w badaniach biegłości } \\
\text { (wartość względna) }\end{array}$ \\
\cline { 2 - 5 } & {$\left[\mathrm{mg} / \mathbf{m}^{3}\right]$} & {$\left[\mathrm{mg} / \mathbf{m}^{3}\right]$} & {$[\%]$} & {$[\%]$} \\
\hline \hline Tetrahydrotiofen THT & 25 & 1,0 & 4 & 20 \\
\hline
\end{tabular}


Podstawą prawidłowego nadzoru metrologicznego nad wyposażeniem pomiarowym są wzorcowania oraz regularne sprawdzenia wskazań urządzeń (opisane w dalszej części artykułu). Trudności w nadzorze pojawiają się w przypadku analizatorów realizujących pomiary on-line w warunkach procesowych, w trybie pracy ciągłej. Spowodowane jest to przede wszystkim brakiem możliwości demontażu urządzenia na czas sprawdzenia. Kontrola takich urządzeń wymaga użycia urządzenia referencyjnego, którym najczęściej jest analizator przenośny lub przewoźny, pracujący w trybie manualnym lub automatycznym. Niestety obecnie brakuje aktów prawnych i normatywnych dotyczących stricte nadzoru metrologicznego nad procesowymi analizatorami chromatograficznymi do pomiarów stężenia środków nawaniających w gazie (z wyjątkiem standardów technicznych IGG, np. ST-IGG-0705:2019).

W opracowaniu metody nadzoru metrologicznego nad analizatorami pracującymi on-line mogą być pomocne wybrane normy i standardy techniczne (np. PN-C-04751:2011, ST-IGG-0705:2019, ISO/TR 16922:2013, ASTM D 716510:2015) oraz literatura (np. NATA, 2013; Hyk i Stojek, 2016). Niestety zapisy tych dokumentów nie dotyczą urządzeń działających w tym samym trybie i służących do pomiaru stężenia związków siarki w gazie, dlatego nie można ich przenieść wprost na analizatory typu ANAT-M. Konieczne jest zatem opracowanie właściwych warunków i metod nadzoru metrologicznego takiego analizatora, które umożliwią kontrolę poprawności jego pracy w warunkach procesowych, czego podjął się Instytut Nafty i Gazu - Państwowy Instytut Badawczy.

Z uwagi na wskazane w standardzie IGG (ST-IGG-0705:2019) zalecenie przeprowadzania pomiarów kontrolnych analizatorów procesowych THT działających on-line urządzeniami pomiarowymi, które cechuje mniejsza niepewność uzyskiwanych wyników pomiarów, przy doborze urząazeń pomiarowych przeznaczonych do wykonywania sprawdzeń analizatorów procesowych należy kierować się właśnie tą zasadą. Oznacza to, że dopuszczalne jest stosowanie w metodzie referencyjnej przyrządów pomiarowych pozwalających na wykonanie pomiarów stężenia środka nawaniającego w gazie w trybie off-line (pomiary laboratoryjne) lub on-line na obiekcie (chromatograficzne analizatory przewoźne), o ile charakteryzują się one większą dokładnością uzyskiwanych wyników, a pomiar wykonywany jest metodą chromatografii gazowej (ST-IGG-0705:2019).

W przypadku analizatorów procesowych ANAT-M, pracujących obecnie w warunkach procesowych i wykonujących pomiary stężenia środka nawaniającego w paliwach gazowych w trybie on-line, wykorzystuje się tę samą metodę analityczną co w aparaturze laboratoryjnej, tzn. metodę chromatografii gazowej z detektorami specyficznymi dla związków siarki (tu: detektor elektrochemiczny ED) (Huszał, 2011).

\section{Charakterystyka analizatorów procesowych THT i urządzeń referencyjnych}

Jak już wspomniano powyżej, dominującą metodą nadzoru procesu nawonienia paliw gazowych jest pomiar stężenia środka nawaniającego w gazie, realizowany poprzez pomiary wykonywane w sposób off-line lub on-line (Laszuk, 2016). W obu przypadkach wykorzystywanych jest wiele rozwiązań technicznych. Zestawienie wybranych, reprezentatywnych dla ww. metod pomiarów stężenia THT urządzeń pomiarowych wraz $\mathrm{z}$ ich parametrami funkcjonalnymi przedstawiono w tabeli 2 .

Niezawodna i umożliwiająca otrzymanie wiarygodnych wyników analiza zawartości środków nawaniających w gazie

Tabela 2. Zestawienie parametrów urządzeń stosowanych do chromatograficznego oznaczania stężenia THT w gazie (INiG - PIB, 2009' ; Morozewicz, 2016²)

Table 2. Devices parameters used for the chromatographic determination of THT concentration in the gas (INiG - PIB, 2009' ; Morozewicz, 2016²)

\begin{tabular}{|c|c|c|c|}
\hline Sposób pomiaru & Laboratoryjny/off-line & Pomiary okresowe/on-line & Pomiary procesowe/on-line \\
\hline Urządzenie & chromatograf laboratoryjny & analizator chromatograficzny przewoźny & analizator procesowy (ANAT-M) \\
\hline Detektor & PFPD & ED & ED \\
\hline Specyfika detektora & specyficzny dla zw. siarki & specyficzny dla zw. siarki & specyficzny dla THT \\
\hline $\begin{array}{l}\text { Liniowość odpowiedzi } \\
\text { detektora }\end{array}$ & $10^{3}$ dla zw. siarki & w całym zakresie mierzonych stężeń & w całym zakresie mierzonych stężeń \\
\hline Dokładność wskazań & $\begin{array}{l}\text { deklarowana: } \pm 5 \% \\
\text { wyznaczona }^{1}: \pm 1 \%\end{array}$ & $\begin{array}{l}\text { deklarowana: } \pm 5 \% \\
\text { wyznaczona }^{2}: \pm 5 \%\end{array}$ & $\begin{array}{c}\text { deklarowana i wyznaczona przez } \\
\text { INiG-PIB }{ }^{2}: \pm 7 \%\end{array}$ \\
\hline Precyzja & wyznaczona $^{1}: 1,5-2 \%$ & wyznaczona $2 \%$ & wyznaczona 2 : $2-3 \%$ \\
\hline Niepewność rozszerzona & wyznaczona $^{1}: \pm 9,0 \%$ & wyznaczona $^{2}: \pm 8,2 \%$ & wyznaczona $^{2}: \pm 9,9 \%$ \\
\hline Zakres pomiarowy & $\begin{array}{c}\text { zakres stosowania metody } \\
\text { w analizach THT: } 0-200 \mathrm{mg} / \mathrm{m}^{3}\end{array}$ & $0-100 \mathrm{mg} / \mathrm{m}^{3}$ & $5-100 \mathrm{mg} / \mathrm{m}^{3}$ \\
\hline Sposób dozowania próbki & manualny & manualny lub automatyczny & automatyczny \\
\hline
\end{tabular}


jest trudnym zadaniem analitycznym. W przypadku pomiarów stężenia nawaniaczy w gazie wyniki charakteryzujące się możliwie najwyższym stopniem precyzji można uzyskać jedynie przy użyciu metod chromatograficznych. W rutynowych pomiarach stężenia THT w gazie stosowane są zarówno chromatografy laboratoryjne, jak i analizatory chromatograficzne, wyposażone w detektory pozwalające na selektywne oznaczanie wybranego związku siarki (tu: THT) (Szlęk i Holewa, 2015). Zamienne stosowanie obu rodzajów przyrządów pomiarowych jest metrologicznie poprawne, o ile charakteryzują się one podobną niepewnością wskazań (PN-EN ISO 19739:2010).

W ostatnich latach zyskują na popularności urządzenia pomiarowe mogące pracować on-line w warunkach obiektowych, przystosowane do przekazywania wyników pomiarów zdalnie, w czasie rzeczywistym (Holewa i Szlęk, 2013; Laszuk, 2017). Zgodnie $\mathrm{z}$ tą tendencją $\mathrm{w}$ gazownictwie coraz powszechniejsze staje się stosowanie chromatograficznych analizatorów on-line przeznaczonych do pomiarów stężenia THT w gazie, spełniających wymagania PN-EN ISO 19739:2010. Przez analizator on-line pracujący w warunkach obiektowych należy tu rozumieć urządzenie pomiarowe działające bezobsługowo w warunkach procesowych, w którym wszystkie czynności związane $\mathrm{z}$ analizą próbki (w tym także pobór próbki i zdalny przekaz wyniku pomiaru) odbywają się automatycznie. Tego typu pomiar jest ważnym elementem prowadzenia i monitorowania procesu nawaniania paliw gazowych, a jakość uzyskiwanych wyników pomiarów, przy zachowaniu odpowiednich warunków prowadzenia kontroli, może być porównywalna z jakością wyniku otrzymanego przy użyciu chromatografów laboratoryjnych. Urządzenia te są wpisane w schemat nadzoru nad jakością nawonienia gazu w sieci dystrybucyjnej (Laszuk, 2016, 2017). Obecnie jedynymi stosowanymi w Polsce w systemie nadzoru procesu nawaniania paliw gazowych procesowymi analizatorami do kontroli stężenia THT są analizatory typu ANAT-M. Dlatego badania podjęte przez Zakład Nawaniania Paliw Gazowych INiG - PIB dotyczą metod nadzoru tylko i wyłącznie nad tymi urządzeniami procesowymi.

Chromatograficzne analizatory procesowe ANAT-M posiadają wbudowane niezależne systemy samoczynnego sprawdzania, pozwalające na wykonywanie pomiarów kalibracyjnych (tzw. autokalibracja wewnętrzna) okresowo lub każdorazowo przed pomiarem właściwym. Jednakże dla kontroli właściwej pracy urządzeń procesowych niezbędne jest również wykonywanie sprawdzeń lub wzorcowania zewnętrznego, np. przez pomiary referencyjne/porównawcze. Sprawdzenie odpowiedzi analizatora na znane stężenie mierzonego związku jest niezbędne dla zapewnienia odpowiedniej jakości uzyskiwanych danych pomiarowych.

Dotychczasowe doświadczenia eksploatacyjne potwierdziły niezawodność pracy analizatorów ANAT-M, jak również wiarygodność ich wskazań (tylko w warunkach pełnego nadzoru nad urządzeniem) w warunkach procesowych. Na rysunku 1 przedstawione są przykładowe rzeczywiste potwierdzenia sprawności pracy urządzeń w warunkach obiektowych (wykonujących pomiary on-line) zebrane na podstawie pomiarów sprawdzających wykonanych przez INiG - PIB metodą referencyjną (pomiary okresowe on-line) w latach 2008-2014.

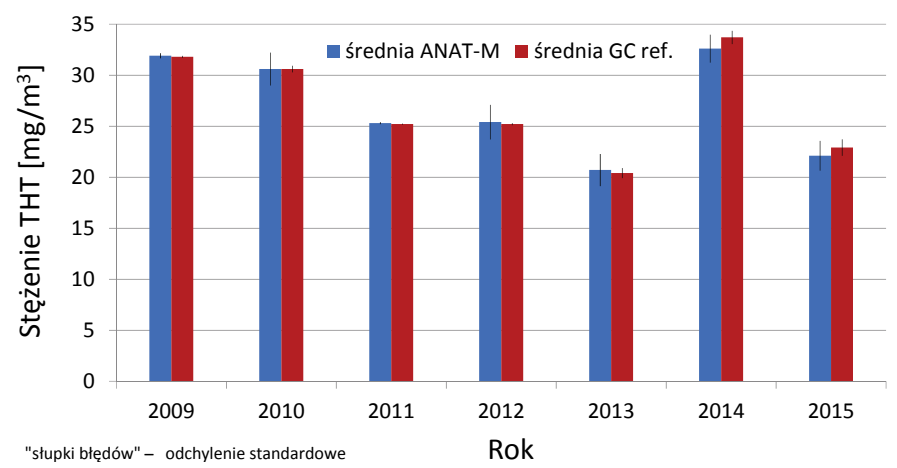

Rys . 1. Wyniki sprawdzeń analizatora ANAT-M metodą pomiarów porównawczych on-line w warunkach procesowych, prowadzonych w latach 2008-2015

Fig. 1. Results of the ANAT-M analyzer checks with the use of on-line reference measurements under process conditions carried out in 2008-2015

Trudności w nadzorze metrologicznym analizatorów procesowych realizujących pomiary on-line w trybie pracy ciągłej spowodowane są przede wszystkim brakiem możliwości demontażu urządzenia na czas sprawdzenia. Do sprawdzania tych urządzeń konieczne jest stosowanie metody, która umożliwia kontrolę poprawności ich pracy w warunkach procesowych (metoda referencyjna). Kontrola taka wymaga użycia urządzenia referencyjnego, którym w praktyce najczęściej jest analizator przenośny lub przewoźny pracujący w trybie automatycznym.

\section{Stosowane modele sprawdzania analizatorów procesowych THT typu ANAT-M}

Wśród metod aktualnie stosowanych do sprawdzenia poprawności wskazań analizatorów procesowych służących do kontroli stężenia THT w gazie wyróżnić można:

- metodę porównania z testem laboratoryjnym (Laszuk, 2016, 2017) (metoda analogiczna do metody off-line wykonywania pomiarów stężenia THT w gazie);

- metodę pomiarów porównawczych on-line (Huszał, 2011) (metoda analogiczna do metody on-line wykonywania pomiarów stężenia THT w gazie).

Metody te można scharakteryzować następująco:

I. Metoda porównania $\mathrm{z}$ testem laboratoryjnym - polega na porównaniu wyników pomiarów wykonanych sprawdzanym 
analizatorem z wynikami otrzymanymi chromatografem w laboratorium. Porównaniu podlegają wyniki uzyskane dla próbek gazu pobranych w tym samym punkcie pomiarowym sieci gazowej (zwykle punkt poboru próbki gazu do analizatora THT), pobranych w tym samym czasie. Wiąże się to z koniecznością transportu próbki do laboratorium sprawdzającego, z uwagi na fakt, że sprawdzenie powinno dotyczyć tej samej próbki gazu. Podstawową wadą praktyki stosowanej w tym obszarze jest wykonywanie zwykle jednej analizy laboratoryjnej (liczba powtórzeń dla 1 próbki $\leq 3$ ), stąd granicą dokładności metody jest odtwarzalność testu laboratoryjnego.

II. Metoda pomiarów porównawczych on-line - polega na ocenie poprawności wskazań analizatora poprzez porównanie z wynikami uzyskanymi przez urządzenie referencyjne włączone do układu procesowego równolegle. Dużą zaletą tej metody jest wykonanie sprawdzenia dla dokładnie tej samej próbki gazu. Za jej wadę należy uznać to, że porównaniu poddawane mogą być jedynie pojedyncze wyniki uzyskiwane dla tej samej próbki badanej.

Charakterystykę urządzeń pomiarowych wykorzystywanych przez INiG - PIB w obu metodach nadzoru analizatorów procesowych typu ANAT-M oraz samego analizatora procesowego przedstawiono w tabeli 2.

Do niewątpliwych zalet obu ww. metod należy przeprowadzanie sprawdzenia poprawności wskazań bądź wzorcowania urządzenia procesowego z użyciem próbki rzeczywistej bez konieczności przerywania pracy analizatora. Z kolei zasadniczą ich wadą jest możliwość jedynie jednopunktowego sprawdzenia urządzeń, stąd granicą dokładności może być odtwarzalność stosowanego testu sprawdzającego. Nie ma możliwości określenia odtwarzalności analizatora, gdyż proces cały czas przebiega.

Rozbieżność wyników uzyskanych za pomocą obu metod kontrolnych, oznaczonych jako I i II, spowodowana jest w wielu przypadkach sposobem pobierania próbek (Szczepaniak, 2011). W laboratorium można wykonać dla pobranej próbki kilka oznaczeń i oszacować precyzję oraz odtwarzalność samego oznaczenia, co zwiększa zaufanie do otrzymanych wyników. Mało uwagi przywiązuje się jednak do reprezentatywności próbki, w tym przede wszystkim do warunków jej przechowywania i transportu. Nawet przy założeniu, że próbka jest jednorodna, pomiar procesowy ma taką przewagę nad laboratoryjnym, że odbywa się w stale zmieniającym się strumieniu. Stąd prawdopodobnie wynika ww. rozbieżność wyników testów sprawdzających analizatory procesowe oraz rozbieżność wyników dla tej samej próbki otrzymywanych w trybie off-line i on-line (Nichols, 1981; McLennan i Kowalski, 2012). Ryzyko zmian próbki (a w konsekwencji i wyniku analitycznego pomiaru stężenia THT w gazie) rośnie wraz ze zmianą temperatury, ciśnienia, wydłużeniem czasu kontaktu próbki z próbnikiem, a także odwrotnie proporcjonalnie do malejącego stężenia oznaczanego związku. Jednakże nadal w praktyce pomiarów kontrolnych THT do poprawnego próbkowania przywiązuje się zbyt małą wagę i nie docenia się wkładu tego etapu analizy w końcowy wynik oznaczenia stężenia THT w gazie.

\section{Metody statystyczne oceny wyników pomiarów sprawdzających w procesie nadzoru nad urządzeniami procesowymi do kontroli THT}

Analizatory typu ANAT-M pracujące w warunkach obiektowych nie są poddawane wzorcowaniu zewnętrznemu ze względu na wspomniany brak możliwości demontażu urządzenia. W analizatorach tych dzięki zastosowanej funkcji autokalibracji kalibracja gazem wzorcowym następuje przed każdym pomiarem. Do jej wyniku odnoszone jest każdorazowe wskazanie urządzenia. Podobnie jak w przypadku analizatora referencyjnego stosuje się gazy wzorcowe o stężeniach THT zbliżonych do zakresu spodziewanych stężeń THT w gazie. W warunkach procesowych, poza autokalibracją, urządzenia te poddawane są sprawdzeniom zewnętrznym poprzez pomiary porównawcze wykonywane on-line chromatograficznym analizatorem referencyjnym (metoda pomiarów porównawczych on-line). Częstotliwość tych sprawdzeń ogranicza się zazwyczaj do jednego sprawdzenia na rok. INiG - PIB przeprowadził badania metrologiczne obu urządzeń (nadzorowanego i referencyjnego) $\mathrm{w}$ warunkach stacjonarnych i procesowych w celu sprawdzenia, czy przyjęty sposób dokonywania sprawdzeń jest poprawny. Badania te miały docelowo wskazać właściwą metodę nadzoru metrologicznego analizatorów ANAT-M w warunkach procesowych.

Badania analizatorów podzielone zostały na dwa bloki:

- badania testowe w warunkach statycznych - prowadzone w laboratorium niezależnie dla każdego analizatora według schematu przedstawionego na rysunku 2 ;

- badania porównawcze w warunkach dynamicznych - pomiary porównawcze analizatora ANAT-M prowadzone analizatorem w warunkach obiektowych (stacja gazowa) według schematu przedstawionego na rysunku 3, na którym wyniki otrzymane dla analizatora referencyjnego oznaczone zostały indeksem „manual”, a dla analizatora ANAT-M - indeksem „on-line”.

Badania obejmowały m.in.:

1. analizę wyników pomiarów wykonanych przez oba urządzenia za pomocą jednoczynnikowej analizy wariancji (ANOVA) uwzględniającej wpływ zmian wybranego czynnika środowiskowego - jednorodność wariancji $\mathrm{P}=95 \%$; 


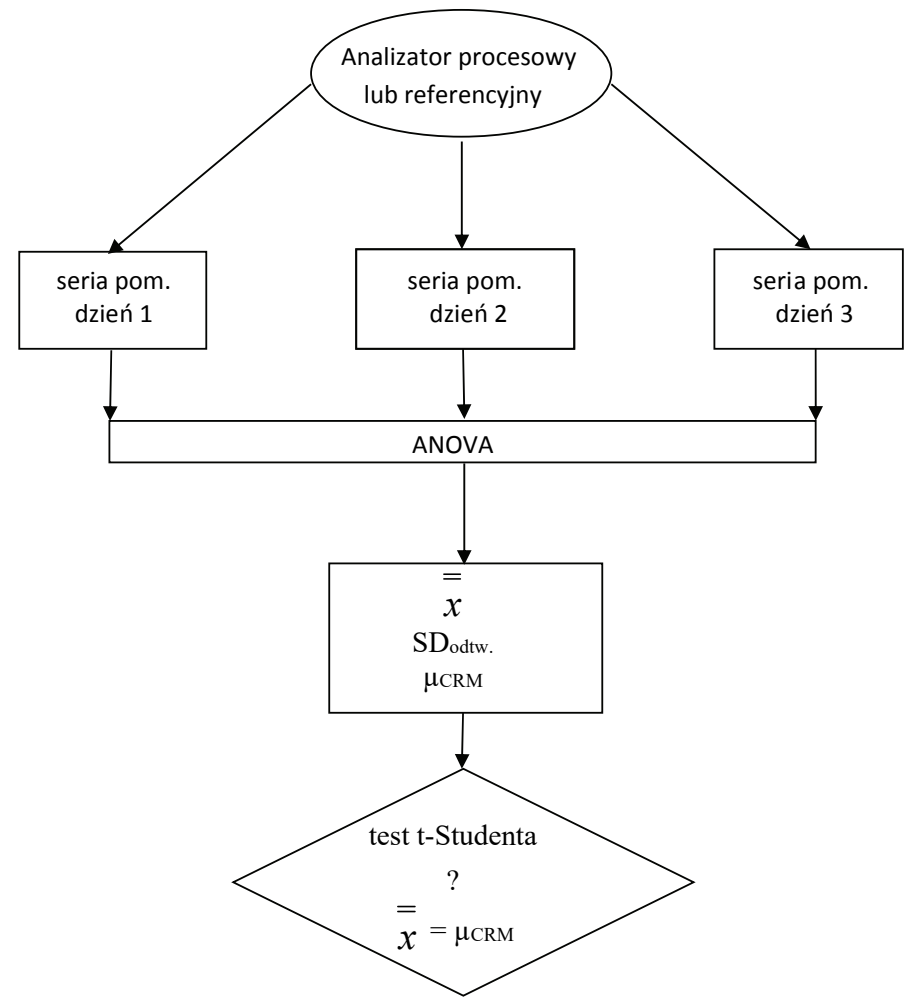

Rys. 2. Schemat oceny statystycznej analizatorów THT w warunkach statycznych (indeks CRM odnosi się do mieszaniny wzorcowej)

Fig. 2. The scheme of statistical evaluation of THT analyzers under static conditions (the CRM index relates to the reference mixture)
2. oszacowanie niepewności wyników pomiarów wykonywanych analizatorem ANAT-M i analizatorem referencyjnym;

3. analizę porównawczą wyników pomiarów wykonanych przez oba urządzenia w warunkach procesowych za pomocą następujących narzędzi statystycznych:

- testu na wykrycie błędów grubych (metoda przedziału ufności),

- jednoczynnikowej analizy wariancji (ANOVA) uwzględniającej wpływ zmian wybranego czynnika środowiskowego (dnia pomiaru) - jednorodność wariancji $\mathrm{P}=95 \%$,

- testu $t$-Studenta $(\mathrm{P}=95 \%)$ porównującego wartości średnie dwóch serii pomiarowych przy określonym poziomie istotności różnic odchyleń standardowych serii pomiarów.

Przykładowe wyniki wszystkich pomiarów uzyskanych w jednej serii dla obu analizatorów przedstawiają rysunki 4 i 5, odnoszące się odpowiednio do warunków stacjonarnych i dynamicznych (miejsce zainstalowania i pracy analizatora procesowego). Na wykresach oprócz uzyskanych wartości stężeń przedstawiono także (prawa oś) odchylenia wyników pomiarów od wartości rzeczywistej (certyfikat mieszaniny wzorcowej THT) lub wartości odniesienia (wskazanie analizatora referencyjnego), odpowiednio dla warunków statycznych i dynamicznych testu.
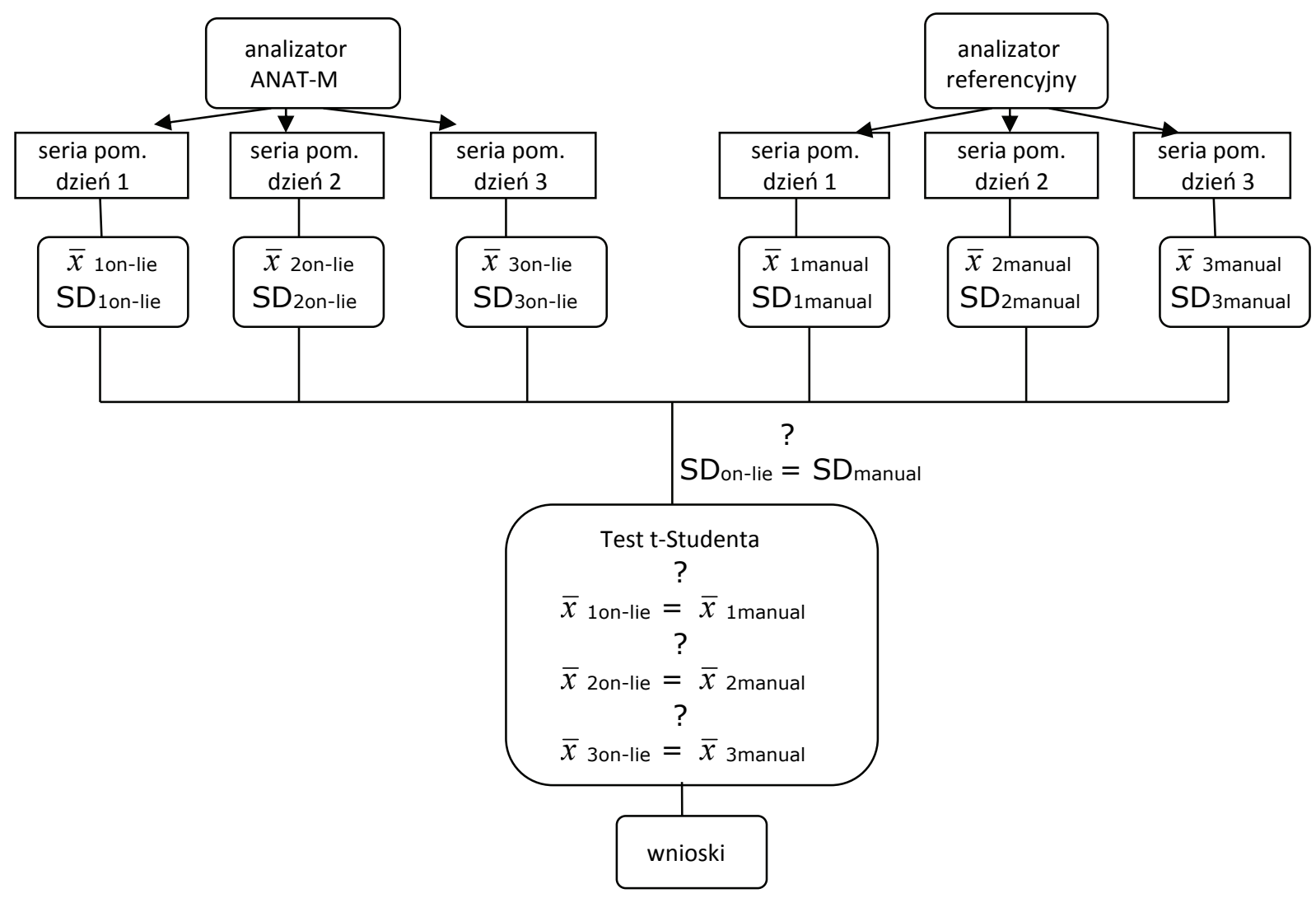

Rys. 3. Schemat oceny statystycznej analizatorów THT w warunkach dynamicznych (indeks CRM odnosi się do mieszaniny wzorcowej)

Fig. 3. The scheme of statistical evaluation of THT analyzers under dynamic conditions (the CRM index relates to the reference mixture) 


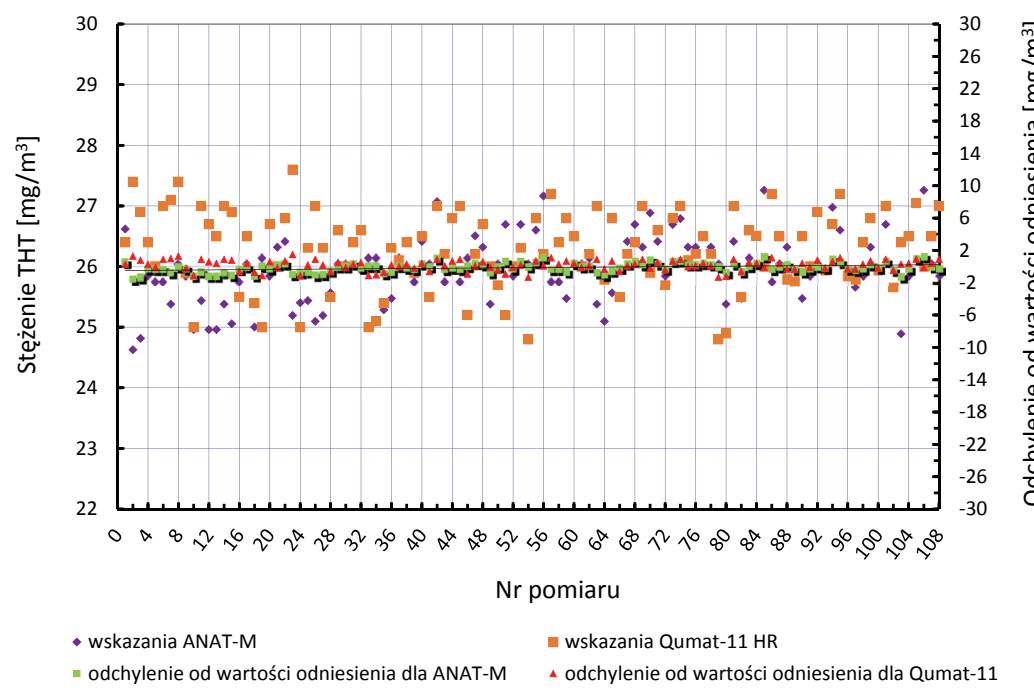

Rys . 4. Wyniki pomiarów analizatora ANAT-M i analizatora referencyjnego uzyskane w warunkach statycznych (laboratoryjnych)

Fig. 4. Measurement results of the ANAT-M analyzer and the reference analyzer obtained under static (laboratory) conditions

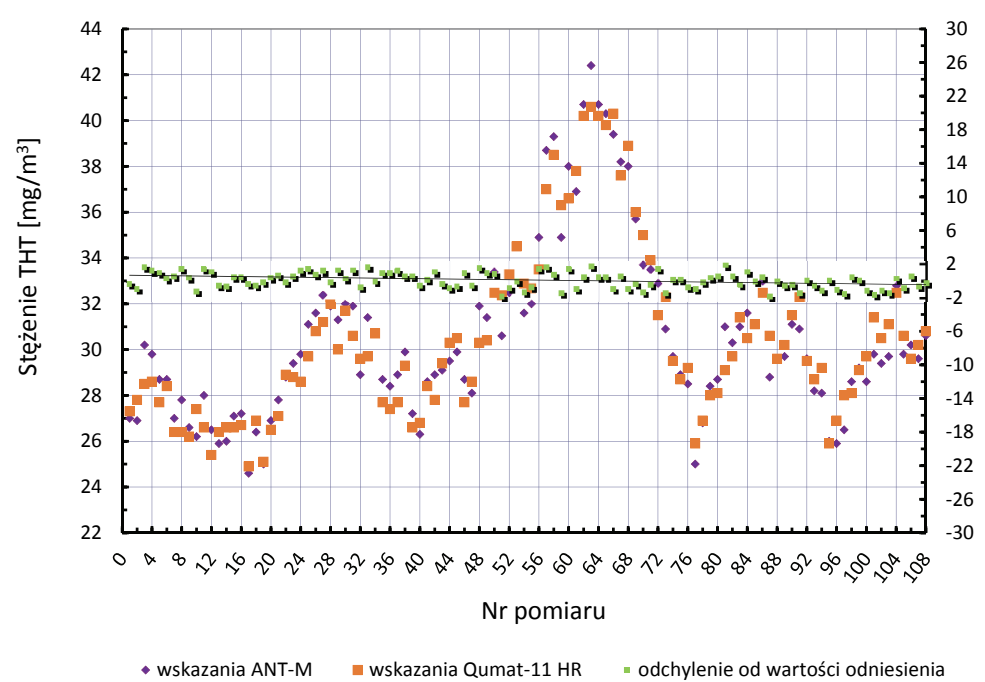

Rys . 5. Wyniki pomiarów analizatora ANAT-M i analizatora referencyjnego uzyskane w warunkach dynamicznych (pomiary on-line)

Fig. 5. Measurement results of the ANAT-M analyzer and the reference analyzer obtained under dynamic conditions (on-line measurements)

W celu oceny statystycznej istotności różnic pomiędzy średnimi uzyskanymi dla poszczególnych serii pomiarów wytypowano jednoczynnikową analizę wariancji ANOVA (Hyk i Stojek, 2016). Dla dwóch grup wyników o rozkładzie normalnym metoda ANOVA z dużym prawdopodobieństwem daje takie same wyniki jak test $t$-Studenta. $\mathrm{W}$ analizie wariancji dla porównania otrzymanej wartości średniej $(\bar{x}) \mathrm{z}$ wartością prawdziwą $\left(\mu_{w z}\right)$ posłużono się parametrem $t_{\text {eksp }}$ wyliczonym ze wzoru (1).

$$
t_{e k s p}=\left(\bar{x}-\mu_{w z}\right) \cdot \frac{\sqrt{n}}{s}
$$

gdzie:

$\bar{x}$ - wartość średnia wyniku dla próbki, $\mu_{w z}$ - wartość rzeczywista,

$n$ - liczba pomiarów,

$s$ - odchylenie standardowe serii wyników.

Wyniki analizy wariancji uzyskane dla urządzeń badanych w warunkach statycznych i dynamicznych (procesowych) przedstawiono w tabelach 3 i 4.

Ponieważ wartość $t_{e k s p}$ jest mniejsza niż $t_{k r y t}$, oznacza to, że wynik średni nie różni się istotnie od wartości rzeczywistej (wartość referencyjna z certyfikatu). Wskazuje to na dużą zgodność wyników analizatorów z wartością rzeczywistą.

Wartości niepewności złożonej wyznaczone dla współczynnika rozszerzenia $k=2(P=95 \%)$ wynoszą odpowiednio:

- dla analizatora ANAT-M: $\pm 9,9 \%$;

- dla analizatora referencyjnego: $\pm 8,2 \%$.

Wartość niepewności uzyskana dla analizatora referencyjnego okazała się porównywalna z wartością niepewności chromatografu gazowego Zakładu Nawaniania Paliw Gazowych INiG - PIB, służącego do oznaczania zawartości THT w gazie w warunkach laboratoryjnych. Wyznaczona wartość niepewności dla chromatografu wynosi około $\pm 9,0 \%$.

Parametr $s_{z b i o r}$ odnosi się do pierwiastka kwadratowego ze zbiorczego odchylenia standardowego, obliczanego ze wzoru:

$$
t_{e k s p}=\left(\bar{x}-\mu_{w z}\right) \cdot \frac{\sqrt{n}}{s}
$$

gdzie $s_{1}$ i $s_{2}$ są wartościami odchylenia standardowego dla wyników uzyskanych każdym analizatorem w jednej serii.

Wyznaczone wartości parametrów $t_{e k s}\left(<t_{k r y t}\right)$ oznaczają, że różnica między uzyskanymi oboma urządzeniami wartościami średnimi nie jest istotna na poziomie ufności $95 \%$. Obie metody pomiaru generują porównywalne statystycznie wyniki pomiarów.

Tabela 3. Wyniki analizy wariancji dla analizatora ANAT-M oraz analizatora referencyjnego $\mathrm{w}$ warunkach statycznych

Table 3. The results of the variance analysis for the ANAT-M analyzer and the reference analyzer under static conditions

\begin{tabular}{|c|c|c|c|}
\hline $\begin{array}{c}\text { Średnia ogólna } \\
\overline{\boldsymbol{x}}\end{array}$ & $\begin{array}{c}\text { Odchylenie standardowe } \\
\text { średniej ogólnej } \\
\boldsymbol{s}\end{array}$ & \multirow{2}{*}{$\boldsymbol{t}_{\text {eksp }}$} & \multirow{2}{*}{$\boldsymbol{t}_{\text {kryt }}$} \\
\hline \multicolumn{3}{|c|}{ Analizator ANAT-M } \\
\hline \hline \multicolumn{3}{|c|}{ Analizator referencyjny } \\
\hline 26,09 & 0,17 & 0,139 & 4,303 \\
\hline 26,07 & 0,12 & 4,303 \\
\hline
\end{tabular}


Tabela 4. Wyniki analizy wariancji uzyskane dla analizatora ANAT-M oraz analizatora referencyjnego $\mathrm{w}$ warunkach dynamicznych (procesowych)

Table 4. The results of the variance analysis obtained for the ANAT-M analyzer and the reference analyzer under dynamic (process) conditions

\begin{tabular}{|c|c|c|c|}
\hline \multirow{2}{*}{$\begin{array}{c}\text { Seria } \\
\text { pomiarowa }\end{array}$} & $\begin{array}{c}\text { Odchylenie standardowe } \\
\text { zbiorcze } \\
\boldsymbol{s}_{\text {zbior }}\end{array}$ & \multirow{2}{*}{$\boldsymbol{t}_{\text {eksp }}$} & \multirow{2}{*}{$\boldsymbol{t}_{\text {kryt }}$} \\
\cline { 2 - 3 } & {$\left[\mathrm{mg} / \mathbf{m}^{3}\right]$} & \\
\hline \hline I & 7,325 & 0,460 & 1,960 \\
\hline II & 3,920 & 0,212 & 1,960 \\
\hline III & 3,715 & 0,401 & 1,960 \\
\hline
\end{tabular}

Badania INiG - PIB wykazały, że zastosowane metody pomiaru stężenia THT w gazie nie różnią się istotnie poprawnością oznaczeń $\left(t_{e k s}<t_{k r y y}\right)$, co wskazuje na możliwość stosowania w nadzorze metrologicznym analizatorów ANAT-M analizatorów chromatograficznych wykonujących pomiary równoległe w trybie on-line.

\section{Obciążenie metod sprawdzania analizatorów procesowych THT}

Z długoletniego doświadczenia Zakładu Nawaniania Paliw Gazowych INiG - PIB w nadzorze nad analizatorami procesowymi THT wynika, że obie zidentyfikowane i opisane powyżej metody sprawdzające poprawność wskazań analizatorów ANAT-M bardzo często nie dają zgodnych wyników. Stąd zaistniała potrzeba eksperymentalnej oceny zgodności wyników sprawdzeń uzyskiwanych metodą porównania $\mathrm{z}$ testem laboratoryjnym $\mathrm{z}$ wynikami sprawdzeń metodą pomiarów porównawczych on-line (prowadzonych obecnie przez INiG - PIB). Charakterystykę urządzeń pomiarowych stosowanych w badaniach rozbieżności wyników testów sprawdzających poprawność wskazań analizatorów procesowych ANAT-M przedstawiono w tabeli 2. Urządzenia te można zdefiniować jako zespoły analityczne do chromatograficznego pomiaru stężenia THT w gazie ziemnym spełniające wymagania normy PN-EN ISO 19739:2010 i standardu technicznego ST-IGG-0705:2019.

Dla obu metod nadzoru metrologicznego analizatorów ANAT-M przeprowadzono analizę obciążenia, która pozwala określić wielkość i rodzaj błędów systematycznych występujących w trakcie wykonywania procedury pomiarowej. Wykrycie błędu statystycznego daje możliwość jego eliminacji poprzez oszacowanie i wprowadzenie odpowiedniego współczynnika korygującego, który eliminuje istotne odstępstwo otrzymywanych wyników pomiaru od wartości rzeczywistej (tu: stężenia THT w gazie). Do wykrycia ewentualnego błędu systematycznego metod wykorzystano właśnie badanie obciążenia wyników pomiarów otrzymywanych obiema metodami. Wykorzystano literaturową procedurę szacowania odzysku (Hyk i Stojek, 2016), w której odzysk rozumiany jest jako wartość średnia analizy materiału certyfikowanego THT odniesiona do wartości certyfikowanej wzorca.

Badania mające na celu porównanie metod sprawdzających poprawność wskazań analizatorów ANAT-M prowadzono zarówno na obiekcie, jak i w laboratorium Zakładu Nawaniania Paliw Gazowych INiG - PIB, w zależności od wymagań danej metody nadzoru. Badania wykonywano wyłącznie dla próbek certyfikowanych wzorców THT w 4 punktach kontrolnych, określonych poziomami stężeń THT. Przeprowadzone badanie istotności odzysku pozwoliło wykazać, czy dana metoda sprawdzania analizatorów ANAT-M jest obarczona błędem systematycznym. Oceny tej dokonano na podstawie wyznaczonych wartości odzysków dla badanych próbek wzorcowych oraz obliczonego średniego odzysku dla danej metody. Wyniki badań zamieszczono w tabeli 5, a parametry metrologiczne badanych urządzeń zestawiono w tabeli 2 .

Powyższe dane dowodzą, że na poziomie ufności $95 \%$ odzysk jest istotnie różny od 1 tylko dla metody porównania $\mathrm{z}$ testem laboratoryjnym. Oznacza to istnienie błędu systematycznego w badanym zakresie stężeń, a w związku z tym wyniki oznaczeń wykonywanych tą metodą są obciążone czynnikiem proporcjonalnym i powinny być odpowiednio korygowane
Tabela 5. Zestawienie wyników odzysku otrzymanych dla wzorców THT dla metody porównania $\mathrm{z}$ testem laboratoryjnym oraz metody pomiarów porównawczych on-line

Table 5. Summary of the recovery results of the THT standards obtained by the method of comparison with the laboratory test and the on-line reference measurement method

\begin{tabular}{|c|c|c|c|c|}
\hline $\begin{array}{l}\text { Nr próbki } \\
\text { wzorcowej }\end{array}$ & $\begin{array}{c}\text { Stężenie THT } \\
\text { we wzorcu } \\
{\left[\mathrm{mg} / \mathrm{m}^{3}\right]}\end{array}$ & $\begin{array}{c}\text { Odzysk } \\
R_{j}\end{array}$ & $\begin{array}{c}\text { Średni } \\
\text { odzysk } \\
\frac{\bar{R}}{}\end{array}$ & $\begin{array}{c}\text { Niepewność } \\
\text { standardowa } \\
\text { odzysku } \\
u\left(R_{j}\right)\end{array}$ \\
\hline
\end{tabular}

\begin{tabular}{|c|c|c|c|c|}
\hline \hline \multicolumn{5}{|c|}{$\begin{array}{c}\text { Wyniki dla metody pomiarów porównawczych on-line } \\
\text { z użyciem analizatora referencyjnego }\end{array}$} \\
\hline 1 & $9,18 \pm 0,09$ & 0,9869 & & 0,0322 \\
\hline 2 & $22,02 \pm 0,22$ & 1,0014 & \multirow{2}{*}{0,9957} & 0,0173 \\
\hline 3 & $36,70 \pm 0,37$ & 0,9918 & & 0,0121 \\
\hline 4 & $73,50 \pm 0,74$ & 1,0028 & & 0,0105 \\
\hline
\end{tabular}

Wyniki dla metody porównania $\mathrm{z}$ testem laboratoryjnym $\mathrm{z}$ użyciem chromatografu gazowego

\begin{tabular}{|c|c|c|c|c|}
\hline 1 & $9,18 \pm 0,09$ & 0,7854 & \multirow{5}{*}{0,8043} & 0,0236 \\
& $22,02 \pm 0,22$ & 0,8365 & 0,0101 \\
\hline 3 & $36,70 \pm 0,37$ & 0,7929 & & 0,0111 \\
\hline 4 & $73,50 \pm 0,74$ & 0,8026 & & 0,0084 \\
\hline
\end{tabular}


o wartość współczynnika, który w badanym przypadku dla zadanych warunków prowadzenia sprawdzeń wyniósł 0,8043. Wyznaczony odzysk na poziomie $80 \%$ spowodowany jest $\mathrm{z}$ dużym prawdopodobieństwem poborem próbki gazu do analizy (w tym głównie transportem i przechowywaniem próbki).

\section{Podsumowanie}

Porównanie metod stosowanych w nadzorze metrologicznym analizatorów procesowych ANAT-M wskazało na istnienie błędu systematycznego w całym zakresie stężeń roboczych dla metody porównania z testem laboratoryjnym. Obecność istotnych różnic w wynikach pomiarów sprawdzających analizatory ANAT-M, wykonywanych metodą porównania $\mathrm{z}$ testem laboratoryjnym oraz metodą pomiarów porównawczych on-line, z dużym prawdopodobieństwem związana jest z etapem poboru, transportu i przechowywania próbek gazu do badań.

Wyniki badań INiG - PIB w zakresie porównania metod nadzoru metrologicznego analizatorów procesowych THT wskazują na możliwość i poprawność stosowania metody pomiarów porównawczych on-line do przeprowadzania okresowych wzorcowań bądź sprawdzeń poprawności działania analizatorów ANAT-M wykonywanych w warunkach procesowych (w miejscu zainstalowania i pracy analizatora procesowego). Proces wzorcowania lub sprawdzania poprawności działania musi się jednak odbywać w możliwie jak najstabilniejszych warunkach roboczych sieci gazowej, gwarantujących stabilny poziom stężenia THT w gazie. Niedopuszczalne jest wykonywanie wzorcowania przy gwałtownych zmianach stężenia THT w gazie (z długoletniego doświadczenia Zakładu Nawaniania Paliw Gazowych INiG - PIB w nadzorze nad analizatorami procesowymi THT wynika, że różnice oznaczanego stężenia THT nie powinny być większe niż 20\%).

Powyższa metoda nadzoru metrologicznego analizatora procesowego ANAT-M jest alternatywą dla wzorcowania urządzenia w warunkach laboratoryjnych, gdyż nie wymaga demontażu analizatora na czas dokonywania sprawdzenia.

Artykuł powstał na podstawie pracy statutowej pt. Opracowanie metody nadzoru metrologicznego analizatorów ANAT-M w warunkach obiektowych - praca INiG - PIB na zlecenie MNiSW; nr zlecenia: 0101/WN/2016, nr archiwalny: DK-4100-0101/2016, oraz pracy własnej pt. Określenie przyczyn i wielkości rozbieżności wyników testów sprawdzających poprawność wskazań analizatorów procesowych ANAT-M - praca INiG - PIB na zlecenie MNiSW; nr zlecenia: 0084/WN/2017, nr archiwalny: DK-4100-0071/2017.

\section{Literatura}

Gromadzki K., 2016. Eksploatacja nawanialni wtryskowych Dosador-D. Cz. II. Gaz, Woda i Technika Sanitarna, 7: 238-243.
Holewa J., Szlęk M., 2013. Ocena jakości gazów palnych. Nafta-Gaz, 6: $450-454$.

Huszał A., 2011. Monitoring w trybie on-line. ANAT-M w zautomatyzowanych systemach kontroli nawonienia paliw gazowych w Polsce. Rynek Polskiej Nafty i Gazu, 6: 100-104.

Hyk W., Stojek Z., 2016. Analiza statystyczna w laboratorium. Wydawnictwa Naukowe PWN SA, Warszawa. ISBN: 9788301183042.

Laszuk W., 2016. Problematyka wyznaczania i aktualizacji obszarów rozliczeniowych ciepła spalania oraz obszarów nawaniania z wykorzystaniem urządzeń do zdalnego pomiaru parametrów jakościowych. Nafta-Gaz, 8: 651-659. DOI: 10.18668/NG.2016.08.10.

Laszuk W., 2017. Perspektywa automatyzacji procesu kontroli nawonienia w sieci gazowej Polskiej Spółki Gazownictwa. Materiały Konferencyjne Konferencji TOP-GAZ IX edycja ,, Technika opomiarowania gazu dziś i jutro”, Rogów. Referat: 117-121.

McLennan F., Kowalski B.D., 2012. Process Analytical Chemistry. Springer Science \& Business Media. ISBN-10: 9401042624.

Morozewicz M., 2016. Opracowanie metody nadzoru metrologicznego analizatorów ANAT-M w warunkach obiektowych. Praca statutowa INiG-PIB, nr zlec. 0101/WN/2016, Archiwum Instytutu Nafty i Gazu-Państwowego Instytutu Badawczego, Kraków.

NATA, National Association of Testing Authorities, 2013. Guidelines for estimating and reporting measurement uncertainty of chemical test results. Technical Note 33 .

Nichols G.D., 1981. Process Analyzer Sampling Systems. Anal. Chem., 53(3): 489-500.

Szczepaniak W., 2011. Metody instrumentalne w analizie chemicznej. Wydawnictwo Naukowe PWN SA, Warszawa. ISBN: 9788301142100.

Szlęk M., Holewa J., 2015. Optymalizacja metody oznaczania zawartości związków siarki występujących w paliwach gazowych. Nafta-Gaz, 5: 308-313.

INiG - PIB, 2009. W-Q-2 Raport z walidacji oznaczania zawartości THT w gazie ziemnym i mieszaninach gazowych metodą chromatografii gazowej z użyciem chromatografu gazowego VARIAN $450 \mathrm{GC}$ z detektorem PFPD, wydanie 1. Dokumentacja wewnętrzna Instytutu Nafty i Gazu - PIB.

\section{Akty prawne i normatywne}

ASTM D 7165-10:2015 Standard practice for gas chromatograph based on-line/at-line analysis for sulfur content of gaseous fuels.

ISO/TR 16922:2013 Natural gas. Odorization.

PN-C-04751:2011 Gaz ziemny. Ocena jakości.

PN-EN ISO 14532:2017-05 Gaz ziemny. Słownictwo.

PN-EN ISO 19739:2010 Gaz ziemny. Oznaczanie związków siarki metodą chromatografii gazowej.

Rozporządzenie Ministra Gospodarki z dnia 2 lipca 2010 r. w sprawie szczegółowych warunków funkcjonowania systemu gazowego (Dz.U. z 2010 r. nr 133, poz. 891 z późn. zm., tekst jednolity Dz.U. z 2018 r. poz. 1158).

ST-IGG-0705:2019 Nawanianie paliw gazowych. Metody oznaczania zawartości tetrahydrotiofenu (THT).

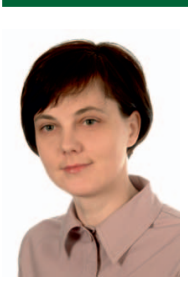

Dr Anna HUSZAL

Adiunkt; kierownik Zakładu Nawaniania Paliw Gazowych

Instytut Nafty i Gazu - Państwowy Instytut Badawczy ul. Lubicz $25 \mathrm{~A}$

31-503 Kraków

E-mail: anna.huszal@inig.pl 